\title{
Mucosal Associated Invariant T Cells in Cancer-Friend or Foe?
}

\author{
Chloe $\mathrm{O}^{\prime}$ Neill $^{1}{ }^{1}$, Féaron C. Cassidy ${ }^{1}$, Donal O'Shea ${ }^{2}$ and Andrew E. Hogan ${ }^{1,3, * \mathbb{C}}$ \\ 1 Lonsdale Human Health Institute, Maynooth University, W23 F2H6 Maynooth, Ireland; \\ Chloe.ONeill@mu.ie (C.O.); Fearon.Cassidy@mu.ie (F.C.C.) \\ 2 St Vincent's University Hospital, University College Dublin, D04 T6F4 Dublin, Ireland; info@dosheaendo.ie \\ 3 National Children's Research Centre, D12 HX96 Dublin, Ireland \\ * Correspondence: Andrew.E.Hogan@mu.ie
}

Citation: O'Neill, C.; Cassidy, F.C.; O'Shea, D.; Hogan, A.E. Mucosal Associated Invariant T Cells in Cancer-Friend or Foe?. Cancers 2021, 13, 1582. https://doi.org/10.3390/ cancers 13071582

Academic Editor: Vasileios Bekiaris

Received: 9 March 2021

Accepted: 26 March 2021

Published: 30 March 2021

Publisher's Note: MDPI stays neutral with regard to jurisdictional claims in published maps and institutional affiliations.

Copyright: (C) 2021 by the authors. Licensee MDPI, Basel, Switzerland. This article is an open access article distributed under the terms and conditions of the Creative Commons Attribution (CC BY) license (https:// creativecommons.org/licenses/by/ $4.0 /)$.
Simple Summary: Mucosal associated invariant T (MAIT) cells are a population of innate T cells which play an important role in host protection against bacterial, fungi and viruses. MAIT cells are armed with potent cytotoxic machinery, allowing them to kill invading pathogens but also transformed cells. Many studies have investigated MAIT cells in the setting of various human cancers, with conflicting results. Several studies have identified MAIT cells as potent anti-cancer effector cells, whilst others have reported a potential pathogenic role for MAIT cells in certain cancers. In this review, we discuss the current knowledge base and highlight potential mechanisms which may underpin the reported cancer-related alterations in MAIT cells.

\begin{abstract}
Mucosal associated invariant T (MAIT) cells are a population of unconventional T cells which can bridge the innate and adaptive immune systems. Well-described roles for MAIT cells include host protection against invading bacteria, fungi and viruses. Upon activation, MAIT cells become prolific effector cells, capable of producing a range of cytokines and lytic molecules. In addition to their anti-microbial role, MAIT cells have been implicated in immune responses to cancer, with opposing beneficial and pathogenic roles reported. On the one hand, MAIT cells can home to the site of the tumour in many human cancers and can produce anti-tumour molecules. On the other, MAIT cells can display defective phenotypes in certain cancers and produce pro-tumour molecules. In this review, we discuss the current literature on the diverse roles for MAIT cells in cancer, outlining their frequencies, functions and associations with $\mathrm{N}$ staging and prognosis. We also discuss potential mechanisms underpinning cancer-related alterations in MAIT cells and highlight therapeutic approaches to harness or target MAIT cells in cancer.
\end{abstract}

Keywords: MAIT cells; cancer; immune checkpoint; metabolism

\section{Introduction}

Mucosal Associated Invariant T (MAIT) cells are a population of unconventional T cells which are enriched in mucosal tissues such as the lung and gut but are also present in other tissues including the skin, adipose tissue and the liver [1-4]. In humans, MAIT cells represent between $1-8 \%$ of $\mathrm{T}$ lymphocytes in the blood, up to $10 \%$ of intestinal $\mathrm{T}$ cells and up to $50 \%$ of all $\mathrm{T}$ cells in the liver [2]. Unlike conventional $\mathrm{T}$ cells, MAIT cells are not restricted by MHC but recognize the MHC-related protein MR1. MAIT cells express a semi-invariant TCR $\alpha$-chain (V $\alpha 7.2-\mathrm{J} \alpha 33 / 20 / 12$ in humans) and a limited repository of TCR- $\beta$ chains, mostly from the TRBV20 and TRBV6 gene families $[5,6]$. They recognize vitamin $B$ metabolites synthesized by bacteria and yeast that are bound to MR1 molecules [7,8]. Vitamin B metabolism pathways are conserved among a broad range of species, enabling MAIT cell recognition of a diverse range of pathogens [9,10]. MAIT cells can also be activated independent of TCR engagement, via pro-inflammatory cytokines such as IL-18 [11-13]. Upon activation, MAIT cells can rapidly respond, producing a milieu of cytokines including interferon-gamma (IFN $\gamma)$, tumour necrosis factor alpha (TNF $\alpha)$ and 
interleukin-17 (IL-17) [12,14]. MAIT cell cytokine profiles can vary depending on their tissue localization [15]. Peripheral MAIT cells are potent producers of IFN $\gamma$ and TNF $\alpha$, whereas IL-17 producing MAIT cells are rare in the periphery but are more abundant in, for example, the female genital mucosa [16]. We have also noted IL-10 production by MAIT cells in the adipose tissue but not the periphery of healthy individuals [3]. In addition to cytokine production, MAIT cells are also prolific producers of cytotoxic proteins such as perforin, granzymes and granulysin (Figure 1) $[9,12,17]$. Granule exocytosis is the most common mechanism by which cytotoxic cells mediate apoptosis in tumour cells, relying on granzymes to enter the tumour cell cytoplasm via pores formed by perforins [18]. MAIT cells express granzymes A and $\mathrm{K}$ constitutively and upon activation upregulate perforin and granzyme B expression [17]. Armed with this killing machinery, MAIT cells have been shown to be potent killers of transformed cells $[19,20]$. When paired with their reported presence within numerous human tumour types, these findings have brought MAIT cells into focus in the setting of cancer, highlighting them as a potential novel target for cancer immunotherapy. In this review, we outline the current literature on MAIT cells in cancer, discussing their opposing roles, mechanisms of dysregulation and potential as a therapeutic agent.

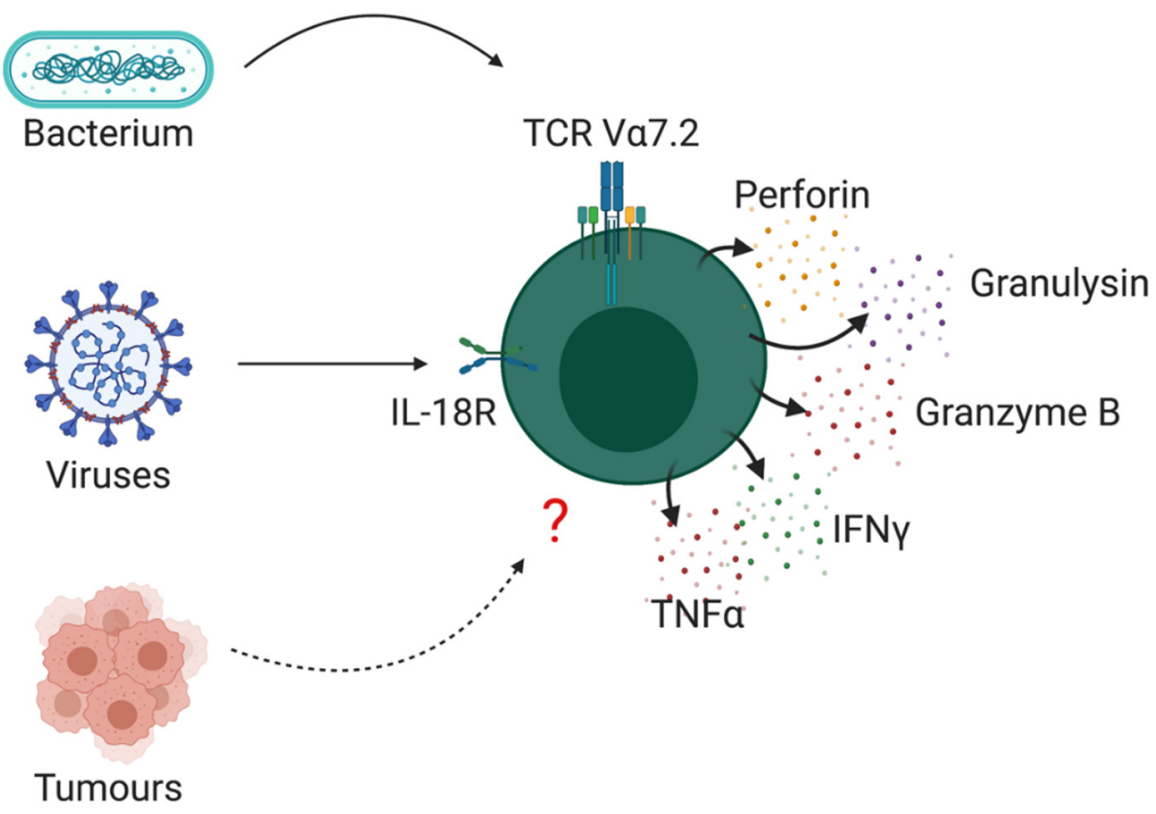

Figure 1. Schematic outlining MAIT cells effector cytokines and killing machinery.

\section{MAIT Cells in Cancer}

MAIT cells have been detected within numerous human tumour types, such as cervical, colorectal, oesophageal, liver, kidney and brain cancer as well as having modified characteristics in the blood of people with multiple myeloma (Table 1) [19,21-28]. The impact of the cancer on MAIT cell frequency, phenotype and function, and conversely the impact of MAIT cells on the cancer can vary greatly from cancer to cancer. We will now discuss MAIT cells in individual cancer types.

\subsection{Colorectal Cancer}

Colorectal cancer (CRC) typically develops from the growth of adenomatous polyps which can lead to impairments in epithelial barrier function and disrupted mucosal homeostasis, resulting in inflammation [29]. The risk of CRC is also mediated by diseases such as ulcerative colitis and Crohn's disease. Several studies have investigated MAIT cells in the setting of CRC and have found that MAIT cells are enriched in neoplasms and CRC tumours compared to healthy colon or peripheral blood $[25,30]$. Li et al., also 
investigated MAIT cell infiltration in CRC tumours, and determined that infiltration was tumour site-specific, as MAIT cells were enriched in CRC when compared to non-small cell lung cancer (NSCLC) and renal cell carcinoma (RCC) tumours [31]. Increased MAIT cell infiltration into tumours was associated with reduced overall survival (OS) and disease-free survival (DFS) in patients living with CRC, potentially suggesting a pathogenic role within colorectal cancer [32]. Functionally MAIT cells were found to be impaired, with reduced IFN $\gamma$ production $[21,22]$. This impairment was associated with proximity to the tumour, with tumour-margin MAIT cells producing more IFN $\gamma$ than tumour-infiltrating MAIT cells [22]. In addition to reduced IFN $\gamma$ production, Kelly and colleagues demonstrated that chronically activated MAIT cells are potent producers of IL-13. The receptor for IL-13 is abundantly expressed in CRC tumours and precancerous polyps, and can act as a protumour factor [33]. Reduced IFN $\gamma$ production and the production of IL-13 may explain the negative association with MAIT cells and outcomes in CRC. However, other studies have demonstrated that MAIT cells retain their IFN- $\gamma$ production and display a strong cytotoxic function within CRC tumours $[25,30]$. In addition to IFN $\gamma$, Ling and colleagues also reported elevated IL-17A production by MAIT cells in both the periphery and tumours of patients with CRC [30]. IL-17 producing MAIT cells have been implicated in numerous chronic inflammatory diseases [14], with one study demonstrating a negative role for IL-17 producing MAIT cells in murine models of melanoma, driven by IL-17 inhibition of natural killer (NK) cell responses [34]. Whether MAIT cells have a positive or negative role in anti-tumour immunity in CRC remains a point of debate and will require further work to elucidate the mechanisms underpinning the reported alterations.

Table 1. Overview of MAIT cell frequencies, cytokine profile and cytotoxic molecule production in cancer.

\begin{tabular}{|c|c|c|c|c|}
\hline Cancer Type & MAIT Cell Frequencies & $\begin{array}{l}\text { MAIT Cell } \\
\text { Cytokines }\end{array}$ & $\begin{array}{c}\text { MAIT Cell } \\
\text { Cytotoxic Molecules }\end{array}$ & Ref \\
\hline \multirow[t]{7}{*}{ Colorectal } & $\uparrow$ in tumour & $\downarrow \mathrm{IFN} \gamma$ & $\uparrow$ Granzyme B & {$[15]$} \\
\hline & $\uparrow$ in tumour & & $\begin{array}{l}\uparrow \text { Granzyme B } \\
\uparrow \text { Perforin } \\
\uparrow \text { CD107a }\end{array}$ & {$[25]$} \\
\hline & $\begin{array}{l}\downarrow \text { in periphery } \\
\uparrow \text { in tumour }\end{array}$ & No change IFN $\gamma, \mathrm{IL}-17, \mathrm{TNF}-\alpha$ & $\begin{array}{l}\uparrow \text { Granzyme B } \\
\uparrow \text { Perforin }\end{array}$ & [20] \\
\hline & $\downarrow$ in CRC liver metastases & $\downarrow \mathrm{IFN} \gamma$ & $\downarrow$ Granzyme B & {$[22]$} \\
\hline & $\begin{array}{l}\downarrow \text { in periphery } \\
\uparrow \text { in tumour }\end{array}$ & $\begin{array}{l}\downarrow \mathrm{IFN} \gamma \text { in periphery } \\
\uparrow \mathrm{IFN} \gamma \text { in tumour } \\
\uparrow \mathrm{IL}-17 \text { in tumour }\end{array}$ & & {$[30]$} \\
\hline & $\uparrow$ in tumour & & & {$[31]$} \\
\hline & No change & $\uparrow I L-13$ & & {$[33]$} \\
\hline Multiple Myeloma & $\downarrow$ in periphery & $\begin{array}{c}\downarrow \mathrm{IFN} \gamma, \mathrm{IL}-17, \mathrm{IL}-22 \text { in untreated } \\
\text { patients }\end{array}$ & & [19] \\
\hline Breast & No change in periphery & $\begin{array}{l}\uparrow \mathrm{IL}-17 \text { in breast duct } \\
\downarrow \mathrm{IFN} \gamma \text { in breast duct }\end{array}$ & & [28] \\
\hline Hepatocellular & $\downarrow$ in periphery \& tumour & $\downarrow$ IFN $\gamma$, IL-17, IL-8 & $\begin{array}{c}\downarrow \text { Granzyme B } \\
\downarrow \text { Perforin }\end{array}$ & {$[26]$} \\
\hline Oesophageal & $\begin{array}{l}\downarrow \text { in periphery } \\
\uparrow \text { in tumours }\end{array}$ & $\downarrow \mathrm{IFN} \gamma \& \mathrm{TNF}-\alpha$ & & [23] \\
\hline Gastric & $\downarrow$ in periphery & $\begin{array}{c}\text { Unchanged IFN } \gamma \& \text { TNF- } \alpha \\
\downarrow \text { IL-17 }\end{array}$ & $\downarrow$ Granzyme B & {$[35]$} \\
\hline Lung & $\begin{array}{l}\downarrow \text { in periphery } \\
\uparrow \text { in cancer tissue }\end{array}$ & $\begin{array}{l}\text { Unchanged IFN } \gamma \text {, } \\
\text { TNF- } \alpha, \text { IL-17 }\end{array}$ & $\begin{array}{l}\uparrow \text { Granzyme B } \\
\uparrow \text { Perforin }\end{array}$ & {$[20]$} \\
\hline Kidney & & IFN $\gamma \&$ IL-17 & & {$[27]$} \\
\hline Cervical & $\begin{array}{l}\downarrow \text { in periphery } \\
\uparrow \text { in periphery }\end{array}$ & & & $\begin{array}{l}{[36]} \\
{[24]}\end{array}$ \\
\hline Melanoma & $\begin{array}{l}\downarrow \text { in periphery of non-responders } \\
\text { to PD- } 1 \text { therapy }\end{array}$ & $\begin{array}{c}\uparrow \text { IFN } \gamma \text { in periphery of } \\
\text { non-responders to PD-1 therapy }\end{array}$ & $\begin{array}{l}\uparrow \text { Granzyme B in periphery of } \\
\text { non-responders to PD-1 therapy }\end{array}$ & {$[37]$} \\
\hline
\end{tabular}




\subsection{Multiple Myeloma}

Multiple Myeloma (MM) is a haematological malignancy that is distinguished by the uncontrolled outgrowth of plasma cells from the bone marrow [38]. In 2018, Gherardin et al. reported reduced MAIT cell frequencies in patients with untreated MM compared to healthy controls. The decline in frequency was even greater in patients with refractory/relapsed (R/R) MM [19]. The reduced frequencies were not associated with redistribution to the bone marrow, but elevated expression of CD27 was noted suggesting an exhausted phenotype. Functionally, MAIT cells from untreated MM expressed lower levels of IFN $\gamma$ production, but this was restored in $\mathrm{R} / \mathrm{R}$ MM patients. The exact role MAIT cells play in MM remains unclear, however the authors did demonstrate that MAIT cells were capable of killing myeloma cell lines suggesting potential for harnessing MAIT cells as an immunotherapy [19].

\subsection{Breast Cancer}

Breast cancer is the most frequent malignancy in women globally [39]. Although MAIT cells have not been investigated in primary breast tumours, Zumwalde and colleagues showed that healthy human breast ducts contain a population of MAIT cells bearing a distinct $\mathrm{T}$ cell receptor $\mathrm{V} \beta$ usage [28]. Breast ducts contain higher frequencies of IL-17 producing MAIT cells in comparison to the periphery. In the same study, the authors showed that MDA-MB-231 breast carcinoma cells were capable of activating breast MAIT cells in a TCR-ve, MR1-ve, and microbe-dependent manner, resulting in a strong IL-17 bias [28]. Again, the role for IL-17 in cancer remains unclear, with early IL-17 production supporting tumour growth but offering a protective role in established cancer [40]. The negative impact of IL-17 producing MAIT cells on cancer progression might suggest MAIT cells are early producers [34], highlighting a novel therapeutic avenue in cancers such as breast cancer, however further work on the observations by Zumwalde and colleague is required to elucidate a role for MAIT cells in primary breast cancer.

\subsection{Hepatocellular Carcinoma}

Liver cancer is the second leading cause of cancer-related deaths globally. Hepatocellular carcinoma (HCC) represents nearly $90 \%$ of all cases of primary liver cancer [41]. The liver is home to the highest frequency of MAIT cells in humans, up to $50 \%$ of intrahepatic $T$ cells $[2,42]$. Duan and colleagues reported an association between activated/exhausted MAIT cells and poor prognosis in HCC [26]. MAIT cells from HCC tumours expressed higher levels of the inhibitory markers PD-1, CTLA-4 and TIM-3 when compared to healthy liver [26,32]. Frequencies of MAIT cells were lower in both the periphery and tumours of patients with HCC, with the authors suggesting the reduction in tumour infiltrating MAIT cells was a reflection of liver cirrhosis opposed to increased apoptosis [26]. HCC tumours typically develop in a fibrotic or cirrhotic liver [41]. MAIT cells have been shown to be a profibrotic population in chronic liver disease [43]. Using an in vitro system, Hedge and colleagues demonstrated that MAIT cells could drive a pro-inflammatory human hepatic myofibroblast phenotype in an IL-17/TNF $\alpha$ dependent manner [43]. This suggests that MAIT cells could contribute to the progression of HCC. However, MAIT cells from HCC tumours showed reduced IFN $\gamma$ and IL-17 production but did upregulate the pro angiogenic cytokine IL-8, again suggesting a pro-tumour role [26]. Further investigations are required to establish if MAIT cells represent a pathogenic pro-tumour population in HCC, and must consider co-morbid viral infection (a major risk factor for the development of HCC) as a contributor to the observed phenotype [32].

\subsection{Oesophageal Cancer}

Oesophageal cancer is the sixth leading cause of cancer death in the world [44]. Two major subtypes exist, oesophageal squamous cell carcinoma (OSCC) and adenocarcinoma $(\mathrm{OAC})$ which are epidemiologically and pathologically distinct. OAC typically develops from Barrett's mucosa in the lower oesophagus and has a poor prognosis. Barrett's 
oesophagus (BO) is the name used for its pre-malignant inflammatory condition. Melo and colleagues found that the risk of death with OAC is increased with low levels of tumour-infiltrating MAIT cells [23]. This is in agreement with Yao et al. who reported improved prognosis with higher MAIT cell infiltration in OAC [32]. Healthy MAIT cells were able to kill OAC cell lines in vitro, interestingly this was not impacted by the addition of OAC tissue conditioned media, though MAIT cell production of IFN $\gamma$ and TNF $\alpha$ was diminished [23]. The impact of the tumour microenvironment (TME) has emerged as a major research area in immunotherapy but remains relatively unexplored with respect to MAIT cells. This will be discussed in detail in Section 2.13.

\subsection{Gastric Cancer}

Gastric cancers, with gastric adenocarcinoma (GAC) as the most common histological type, represents a considerable global health burden [45]. A recent study by Shao et al. reported that MAIT cells in the peripheral blood were significantly lower in patients with gastric cancer in comparison to healthy controls. Functionally, MAIT cells from patients with gastric cancer produced comparable levels of IFN $\gamma$ and TNF $\alpha$ when compared to healthy controls, demonstrating a preservation of Th1 cytokines, and produced almost undetectable levels of IL-17 [35]. MAIT cell frequencies and function within the tumour were not investigated and will require future studies to determine if MAIT cells are associated with better or worse prognosis in gastric cancer.

\subsection{Lung Cancer}

Lung cancer is one of the most frequently diagnosed cancers and is the leading cause of cancer-related death worldwide. Non-small-cell lung cancer (NSCLC), a heterogeneous class of tumours, represents approximately $85 \%$ of all new lung cancer diagnoses [46]. Small-cell lung cancer (SCLC) makes up the remaining $15 \%$ and is marked by an exceptionally high proliferative rate, early metastasis and poor prognosis [47]. Won and colleagues have demonstrated reduced MAIT cell frequencies in the periphery of patients with lung cancer. Reduced absolute MAIT cell numbers were associated with $\mathrm{N}$ staging, suggesting MAIT cells may imply the stage of cancer progression, however this was in a cohort of mixed cancers, not lung cancer specifically and thus requires further investigation. A study by Yan et al., investigated the role of MAIT cells in a murine model of lung metastasis, and demonstrated reduced tumour initiation, development and metastasis in MAIT cell deficient mice [34]. The authors elegantly demonstrated that MAIT cells suppress NK cell anti-tumour effector functions in a MR1 and IL-17 dependent manner, providing mechanistic evidence for a pathogenic role for MAIT cells [34]. Translational investigations in humans are required to establish if MAIT cells are a true foe in lung cancer, and if they may represent a novel therapeutic target.

\subsection{Kidney Cancer}

Kidney cancer develops from the renal parenchyma with roughly $70 \%$ of cases being renal cell carcinomas [48]. To date, little research has investigated the presence and role of MAIT cells in kidney cancer. In 2008, Peterfalvi et al. detected the invariant V $\alpha 7$.2-J $\alpha 33$ TCR that is characteristic of MAIT cells in kidney tumours, suggesting an infiltration of MAIT cells. Kidney tumours with $V \alpha$ 7.2-J $\alpha 33$ TCR $\alpha$ expression were infiltrated by CD8+ $T$ cells with HLA-DR expression, suggesting an activated state. Local activation of MAIT cells within tumours was suggested to be possible due to the co-expression of MR1 with the invariant MAIT TCR in 10 out of 11 kidney tumours [27].

\subsection{Cervical Cancer}

Cervical cancer develops from cervical intraepithelial neoplasia and often as a result of persistent human papilloma virus (HPV) infection [49]. Lu et al. found that CD8+, CD4+, and highly activated CD38+CD8+MAIT cells were significantly increased in the periphery of cervical cancer patients in comparison to healthy donors [24]. This alteration 
positively correlated with monocytic myeloid-derived suppressor cells (Mo-MDSC). CD8+ MAIT cells displayed higher expression levels of the activation marker CD38 in cervical cancer patients versus healthy donors. Double negative (DN) and PD1+ DN MAIT cells were reduced in the peripheral blood, and a positive association was found between elevated circulating PD1+ DN MAIT cells and progression free survival [24]. Huang and colleagues also investigated the role of MAIT cells in cervical cancer. In contradiction with the study by Lu and colleagues, they found that the percentage of circulating MAIT cells was significantly lower in cervical cancer patients in comparison to healthy controls, even after age adjustment [36]. Huang et al. recruited individuals without pre-malignant disease or any gynaecologic malignancy as healthy controls, whereas Lu et al. enrolled patients with uterine leiomyoma (uterine fibroids) as controls. It may therefore be possible that the contrasting findings regarding MAIT cell frequency may be contributed to by the presence of benign tumours in one group of controls, again more detailed analysis is required to determine the exact role for MAIT cells in cervical cancer.

\subsection{Melanoma}

Melanoma is a malignancy of melanocytes, pigment-producing cells which are found in the skin, iris and rectum [50]. The cutaneous form is responsible for over 55,000 deaths annually [51]. A study by De Biasi and colleagues investigated T cell populations in patients with melanoma commencing anti-PD-1 therapy, and found that a MAIT cell frequency greater than $1.7 \%$ of peripheral $\mathrm{T}$ cells at baseline predicted responsiveness to anti-PD-1 therapy [37]. The authors also noted that MAIT cells with an activated (CD69) and homing (CXCR4) phenotype were more abundant in melanoma patients responding to anti-PD-1 therapy [37]. Cytokine production was also different in responders versus non-responders with higher production of IFN $\gamma$ and granzyme B, perhaps suggesting a protective and beneficial role in melanoma.

\subsection{Mechanisms of Dysregulation}

As discussed, MAIT cells display a wide range of alterations in cancer, ranging from reduced frequencies in the periphery to altered cytokine profiles. Whilst several of the studies reviewed have highlighted a potential role for MAIT cells in cancer as a prognostic marker or therapeutic target, few studies have provided mechanistic evidence underpinning the observed alterations. Drawing on the data available and evidence from other cell populations, we will discuss some potential mechanisms of MAIT cell dysregulation in cancer (Figure 2).

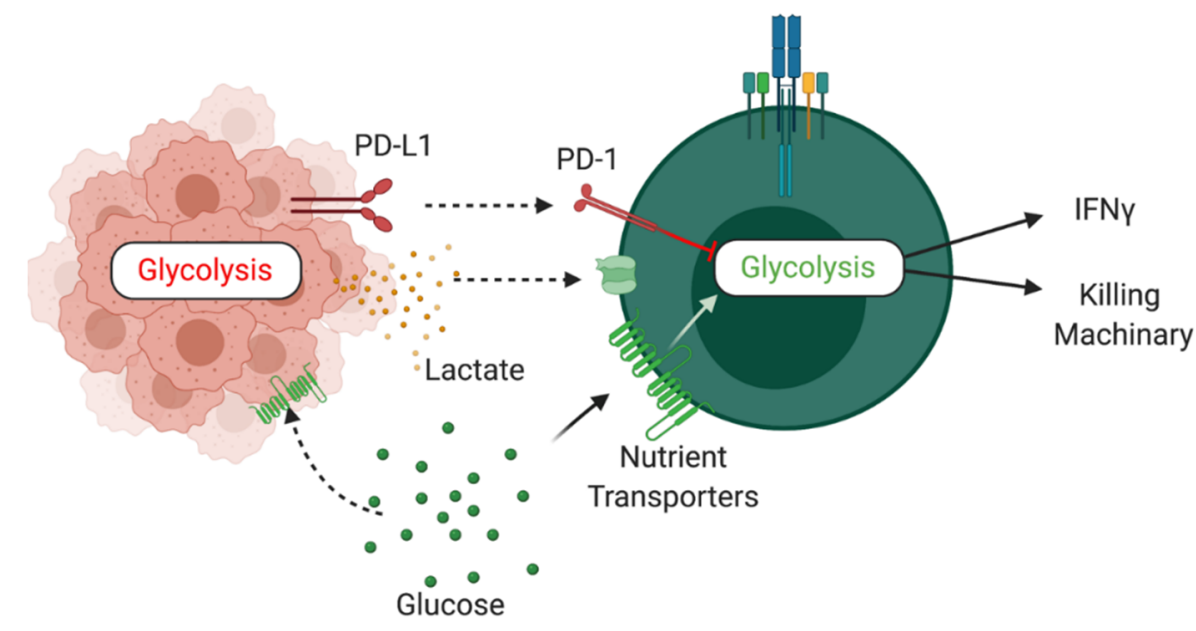

Figure 2. Schematic outlining potential mechanisms of cancer induced dysregulation of MAIT cells. 


\subsection{Immune Checkpoints}

Immune checkpoints refer to a range of inhibitory pathways hardwired into the immune system. These are critical for maintaining self-tolerance and regulating the immune response in order to minimize collateral tissue damage [52]. It is now well established that tumours can target this pathway for immune evasion, in particular avoiding $\mathrm{T}$ cell responses. Two of the most prominent immune checkpoints are PD-1 and CTLA-4. Engagement of these molecules with their respective ligands results in inhibition of $\mathrm{T}$ cell responses [52]. Several studies have highlighted the expression of these immune checkpoints on MAIT cells in human cancers [23,26,31]. Targeting of these immune checkpoints has been highlighted as one of the biggest breakthroughs in cancer therapeutics [53]. Another checkpoint receptor emerging as a potential cancer therapeutic target is T cell immunoglobulin and mucin domain-containing protein 3 (TIM-3) [54]. TIM-3 is highly expressed on dysfunctional and exhausted T cells and can limit IFN $\gamma$ production by conventional T cells. TIM-3 expression was noted on MAIT cells in CRC and HCC [26,31]. To date, studies investigating the impact of checkpoint inhibitors on MAIT cell functions are limited but targeting MAIT cells with checkpoint inhibitors may help harness their anti-tumour effector functions such as IFN $\gamma$ and cytolytic molecule production.

\subsection{Tumour Microenvironment}

Another intense area of research in cancer is the immunosuppressive landscape of the TME. The TME is a highly complex and dynamic ecosystem controlled by the tumour to support its growth and survival [55]. The TME drives immunosuppression via altered levels of metabolites, cytokines, nutrients and oxygen [55]. The TME is also associated with elevated expression of immune checkpoints. Not all patients with cancer respond to checkpoint monotherapy, this is proposed to be due to differences in the TME [56]. Although the impact of the TME has not been directly investigated in MAIT cells, many studies are emerging in other cell types which provide possible avenues for further exploration. One area of great interest is immunometabolism. The harsh TME forces infiltrating cells to undergo metabolic adaptations and can undermine the effectiveness of their responses [57]. Cancer cells are highly glycolytic, this results in limited availability of glucose which can impact the effector functions of infiltrating immune cells [58]. Our research group and others have recently outlined the metabolic requirements of MAIT cells [59-61]. MAIT cells depend on glycolysis for their production of IFN $\gamma$, demonstrating reduced production under acute glucose restriction [60]. Whether the reduced IFN $\gamma$ production by MAIT cells in cancer is linked to restricted glucose availability requires further investigation. Furthermore, glucose restriction can lead to increased rates of apoptosis in conventional T cells $[62,63]$, which might explain the reduced frequencies of MAIT cells in certain cancers [19]. Increased rates of aerobic glycolysis result in elevated levels of lactate which acidifies the TME and can limit immunosurveillance, and T and NK cells [64-66]. Although not investigated to date, another potential driver of MAIT cell dysfunction within the TME is hypoxia, as tumour mass increases it can become hypoxic which can directly inhibit $\mathrm{T}$ cell function $[54,67,68]$. Another unknown is the signals driving the activation of MAIT cells in cancer. Tumour antigen specific $\mathrm{T}$ cells have been reported in numerous cancers, however, to date, tumour-derived antigens capable of activating MAIT cells have not been identified [69-71]. It is well established that the TME contains a milieu of inflammatory cytokines including IL-18 [72], a known driver of MAIT cell activation [11,13]. Interestingly IL-18 has been demonstrated to drive PD-1 dependent immunosuppression in cancer [73]. Whether IL-18 in the TME drives the activation of MAIT cells and/or the expression of PD-1 remains to be explored.

\section{Conclusions}

As highlighted, MAIT cells have diverse roles in cancer. On the one hand, MAIT cells can home to the tumour site and elicit Th1-cytokine response and upregulate cytolytic granule expression $[20,25,30]$. Conversely, MAIT cells can display an exhausted phenotype 
with reduced capacity to produce anti-tumour cytokines, such as IFN $\gamma$ and TNF $\alpha$ [21-23]. Due to their potent effector functions and abundant frequencies in humans, MAIT cells may represent a very attractive therapeutic target for cancer. This is supported by the identification of a MR1-restricted T cell clone capable of killing multiple types of cancer in a TCR-MR1 dependent manner [74]. MAIT cells with their increased expression of PD-1, CTLA-4 and TIM-3 in cancer may be targets for immune-checkpoint inhibitor therapy, potentially restoring MAIT cells anti-tumour abilities. This is supported by the observation that MAIT cell frequency predicted responsiveness to PD-1 therapy [37]. Recently Parrot et al. demonstrated that human MAIT cells could be expanded and engineered for immunotherapy resulting in enhanced cytolytic capacity [75]. However, further research is urgently required to establish if MAIT cells are a friend or foe in cancer, along with the mechanisms underpinning their alterations.

Funding: This research received no external funding.

Institutional Review Board Statement: Not applicable.

Informed Consent Statement: Not applicable.

Data Availability Statement: Not applicable.

Conflicts of Interest: The authors declare no conflict of interest.

\section{References}

1. Provine, N.M.; Klenerman, P. MAIT Cells in Health and Disease. Annu. Rev. Immunol. 2020, 38, 203-228. [CrossRef]

2. Dusseaux, M.; Martin, E.; Serriari, N.; Péguillet, I.; Premel, V.; Louis, D.; Milder, M.; Le Bourhis, L.; Soudais, C.; Treiner, E.; et al. Human MAIT cells are xenobiotic-resistant, tissue-targeted, CD161hi IL-17-secreting T cells. Blood 2011, 117, 1250-1259. [CrossRef] [PubMed]

3. Carolan, E.; Tobin, L.M.; Mangan, B.A.; Corrigan, M.; Gaoatswe, G.; Byrne, G.; Geoghegan, J.; Cody, D.; O'Connell, J.; Winter, D.C.; et al. Altered distribution and increased IL-17 production by mucosal-associated invariant T cells in adult and childhood obesity. J. Immunol. 2015, 194, 5775-5780. [CrossRef]

4. Constantinides, M.G.; Link, V.M.; Tamoutounour, S.; Wong, A.C.; Perez-Chaparro, P.J.; Han, S.J.; Chen, Y.E.; Li, K.; Farhat, S.; Weckel, A.; et al. MAIT cells are imprinted by the microbiota in early life and promote tissue repair. Science 2019, 366. [CrossRef] [PubMed]

5. Treiner, E.; Duban, L.; Bahram, S.; Radosavljevic, M.; Wanner, V.; Tilloy, F.; Affaticati, P.; Gilfillan, S.; Lantz, O. Selection of evolutionarily conserved mucosal-associated invariant T cells by MR1. Nature 2003, 422, 164-169. [CrossRef]

6. Godfrey, D.I.; Koay, H.F.; McCluskey, J.; Gherardin, N.A. The biology and functional importance of MAIT cells. Nat. Immunol. 2019, 20, 1110-1128. [CrossRef]

7. Kjer-Nielsen, L.; Patel, O.; Corbett, A.J.; Le Nours, J.; Meehan, B.; Liu, L.; Bhati, M.; Chen, Z.; Kostenko, L.; Reantragoon, R.; et al. MR1 presents microbial vitamin B metabolites to MAIT cells. Nature 2012, 491, 717-723. [CrossRef]

8. Corbett, A.J.; Eckle, S.B.; Birkinshaw, R.W.; Liu, L.; Patel, O.; Mahony, J.; Chen, Z.; Reantragoon, R.; Meehan, B.; Cao, H.; et al. T-cell activation by transitory neo-antigens derived from distinct microbial pathways. Nature 2014, 509, 361-365. [CrossRef] [PubMed]

9. Le Bourhis, L.; Martin, E.; Péguillet, I.; Guihot, A.; Froux, N.; Coré, M.; Lévy, E.; Dusseaux, M.; Meyssonnier, V.; Premel, V.; et al. Antimicrobial activity of mucosal-associated invariant T cells. Nat. Immunol. 2010, 11, 701-708. [CrossRef]

10. Toubal, A.; Nel, I.; Lotersztajn, S.; Lehuen, A. Mucosal-associated invariant T cells and disease. Nat. Rev. Immunol. 2019, 19, 643-657. [CrossRef]

11. van Wilgenburg, B.; Scherwitzl, I.; Hutchinson, E.C.; Leng, T.; Kurioka, A.; Kulicke, C.; de Lara, C.; Cole, S.; Vasanawathana, S.; Limpitikul, W.; et al. MAIT cells are activated during human viral infections. Nat. Commun. 2016, 7, 11653. [CrossRef] [PubMed]

12. Lamichhane, R.; Schneider, M.; de la Harpe, S.M.; Harrop, T.W.R.; Hannaway, R.F.; Dearden, P.K.; Kirman, J.R.; Tyndall, J.D.A.; Vernall, A.J.; Ussher, J.E. TCR- or Cytokine-Activated CD8. Cell Rep. 2019, 28, 3061.e3065-3076.e3065. [CrossRef] [PubMed]

13. Ussher, J.E.; Bilton, M.; Attwod, E.; Shadwell, J.; Richardson, R.; de Lara, C.; Mettke, E.; Kurioka, A.; Hansen, T.H.; Klenerman, P.; et al. CD161++ CD8+ T cells, including the MAIT cell subset, are specifically activated by IL-12+IL-18 in a TCR-independent manner. Eur. J. Immunol. 2014, 44, 195-203. [CrossRef] [PubMed]

14. Pisarska, M.M.; Dunne, M.R.; O'Shea, D.; Hogan, A.E. Interleukin-17 producing mucosal associated invariant T cells—Emerging players in chronic inflammatory diseases? Eur. J. Immunol. 2020, 19, 1098-1108. [CrossRef]

15. Dias, J.; Boulouis, C.; Sobkowiak, M.J.; Lal, K.G.; Emgård, J.; Buggert, M.; Parrot, T.; Gorin, J.B.; Leeansyah, E.; Sandberg, J.K. Factors Influencing Functional Heterogeneity in Human Mucosa-Associated Invariant T Cells. Front. Immunol. 2018, 9, 1602. [CrossRef] 
16. Gibbs, A.; Leeansyah, E.; Introini, A.; Paquin-Proulx, D.; Hasselrot, K.; Andersson, E.; Broliden, K.; Sandberg, J.K.; Tjernlund, A. MAIT cells reside in the female genital mucosa and are biased towards IL-17 and IL-22 production in response to bacterial stimulation. Mucosal Immunol. 2017, 10, 35-45. [CrossRef]

17. Kurioka, A.; Ussher, J.E.; Cosgrove, C.; Clough, C.; Fergusson, J.R.; Smith, K.; Kang, Y.H.; Walker, L.J.; Hansen, T.H.; Willberg, C.B.; et al. MAIT cells are licensed through granzyme exchange to kill bacterially sensitized targets. Mucosal Immunol. 2015, 8, 429-440. [CrossRef]

18. Chowdhury, D.; Lieberman, J. Death by a thousand cuts: Granzyme pathways of programmed cell death. Annu. Rev. Immunol. 2008, 26, 389-420. [CrossRef]

19. Gherardin, N.A.; Loh, L.; Admojo, L.; Davenport, A.J.; Richardson, K.; Rogers, A.; Darcy, P.K.; Jenkins, M.R.; Prince, H.M.; Harrison, S.J.; et al. Enumeration, functional responses and cytotoxic capacity of MAIT cells in newly diagnosed and relapsed multiple myeloma. Sci. Rep. 2018, 8, 4159. [CrossRef]

20. Won, E.J.; Ju, J.K.; Cho, Y.N.; Jin, H.M.; Park, K.J.; Kim, T.J.; Kwon, Y.S.; Kee, H.J.; Kim, J.C.; Kee, S.J.; et al. Clinical relevance of circulating mucosal-associated invariant $\mathrm{T}$ cell levels and their anti-cancer activity in patients with mucosal-associated cancer. Oncotarget 2016, 7, 76274-76290. [CrossRef]

21. Sundström, P.; Ahlmanner, F.; Akéus, P.; Sundquist, M.; Alsén, S.; Yrlid, U.; Börjesson, L.; Sjöling, Å.; Gustavsson, B.; Wong, S.B.; et al. Human Mucosa-Associated Invariant T Cells Accumulate in Colon Adenocarcinomas but Produce Reduced Amounts of IFN- $\gamma$. J. Immunol. 2015, 195, 3472-3481. [CrossRef]

22. Shaler, C.R.; Tun-Abraham, M.E.; Skaro, A.I.; Khazaie, K.; Corbett, A.J.; Mele, T.; Hernandez-Alejandro, R.; Haeryfar, S.M.M. Mucosa-associated invariant $\mathrm{T}$ cells infiltrate hepatic metastases in patients with colorectal carcinoma but are rendered dysfunctional within and adjacent to tumor microenvironment. Cancer Immunol. Immunother. 2017, 66, 1563-1575. [CrossRef] [PubMed]

23. Melo, A.M.; O’Brien, A.M.; Phelan, J.J.; Kennedy, S.A.; Wood, N.A.W.; Veerapen, N.; Besra, G.S.; Clarke, N.E.; Foley, E.K.; Ravi, A.; et al. Mucosal-Associated Invariant T Cells Display Diminished Effector Capacity in Oesophageal Adenocarcinoma. Front. Immunol. 2019, 10, 1580. [CrossRef] [PubMed]

24. Lu, Z.; Zhu, M.; Marley, J.L.; Bi, K.; Wang, K.; Zhai, M.; Hu, H.; Guo, P.; Li, C.; Xu, Y.; et al. The combined action of monocytic myeloid-derived suppressor cells and mucosal-associated invariant $\mathrm{T}$ cells promotes the progression of cervical cancer. Int. J. Cancer 2021, 148, 1499-1507. [CrossRef]

25. Sundström, P.; Szeponik, L.; Ahlmanner, F.; Sundquist, M.; Wong, J.S.B.; Lindskog, E.B.; Gustafsson, B.; Quiding-Järbrink, M. Tumor-infiltrating mucosal-associated invariant T (MAIT) cells retain expression of cytotoxic effector molecules. Oncotarget 2019, 10, 2810-2823. [CrossRef]

26. Duan, M.; Goswami, S.; Shi, J.Y.; Wu, L.J.; Wang, X.Y.; Ma, J.Q.; Zhang, Z.; Shi, Y.; Ma, L.J.; Zhang, S.; et al. Activated and Exhausted MAIT Cells Foster Disease Progression and Indicate Poor Outcome in Hepatocellular Carcinoma. Clin. Cancer Res. 2019, 25, 3304-3316. [CrossRef] [PubMed]

27. Peterfalvi, A.; Gomori, E.; Magyarlaki, T.; Pal, J.; Banati, M.; Javorhazy, A.; Szekeres-Bartho, J.; Szereday, L.; Illes, Z. Invariant Valpha7.2-Jalpha33 TCR is expressed in human kidney and brain tumors indicating infiltration by mucosal-associated invariant $\mathrm{T}$ (MAIT) cells. Int. Immunol. 2008, 20, 1517-1525. [CrossRef]

28. Zumwalde, N.A.; Haag, J.D.; Gould, M.N.; Gumperz, J.E. Mucosal associated invariant T cells from human breast ducts mediate a Th17-skewed response to bacterially exposed breast carcinoma cells. Breast Cancer Res. 2018, 20, 111. [CrossRef]

29. Odenwald, M.A.; Turner, J.R. The intestinal epithelial barrier: A therapeutic target? Nat. Rev. Gastroenterol. Hepatol. 2017, 14, 9-21. [CrossRef]

30. Ling, L.; Lin, Y.; Zheng, W.; Hong, S.; Tang, X.; Zhao, P.; Li, M.; Ni, J.; Li, C.; Wang, L.; et al. Circulating and tumor-infiltrating mucosal associated invariant T (MAIT) cells in colorectal cancer patients. Sci. Rep. 2016, 6, 20358. [CrossRef]

31. Li, S.; Simoni, Y.; Becht, E.; Loh, C.Y.; Li, N.; Lachance, D.; Koo, S.L.; Lim, T.P.; Tan, E.K.W.; Mathew, R.; et al. Human TumorInfiltrating MAIT Cells Display Hallmarks of Bacterial Antigen Recognition in Colorectal Cancer. Cell Rep. Med. 2020, 1, 100039. [CrossRef]

32. Yao, T.; Shooshtari, P.; Haeryfar, S.M.M. Leveraging Public Single-Cell and Bulk Transcriptomic Datasets to Delineate MAIT Cell Roles and Phenotypic Characteristics in Human Malignancies. Front. Immunol. 2020, 11, 1691. [CrossRef]

33. Kelly, J.; Minoda, Y.; Meredith, T.; Cameron, G.; Philipp, M.S.; Pellicci, D.G.; Corbett, A.J.; Kurts, C.; Gray, D.H.; Godfrey, D.I.; et al. Chronically stimulated human MAIT cells are unexpectedly potent IL-13 producers. Immunol. Cell Biol. 2019, 97, 689-699. [CrossRef]

34. Yan, J.; Allen, S.; McDonald, E.; Das, I.; Mak, J.Y.W.; Liu, L.; Fairlie, D.P.; Meehan, B.S.; Chen, Z.; Corbett, A.J.; et al. MAIT Cells Promote Tumor Initiation, Growth, and Metastases via Tumor MR1. Cancer Discov. 2020, 10, 124-141. [CrossRef] [PubMed]

35. Shao, C.; Zhu, C.; Zhu, Y.; Hao, J.; Li, Y.; Hu, H.; Si, L.; Zhong, F.; Wang, X.; Wang, H. Decrease of peripheral blood mucosalassociated invariant $\mathrm{T}$ cells and impaired serum Granzyme-B production in patients with gastric cancer. Cell Biosci. $2021,11,12$. [CrossRef] [PubMed]

36. Huang, W.C.; Hsiao, Y.C.; Wu, C.C.; Hsu, Y.T.; Chang, C.L. Less circulating mucosal-associated invariant T cells in patients with cervical cancer. Taiwan J. Obs. Gynecol. 2019, 58, 117-121. [CrossRef] 
37. De Biasi, S.; Gibellini, L.; Lo Tartaro, D.; Puccio, S.; Rabacchi, C.; Mazza, E.M.C.; Brummelman, J.; Williams, B.; Kaihara, K.; Forcato, M.; et al. Circulating mucosal-associated invariant T cells identify patients responding to anti-PD-1 therapy. Nat. Commun. 2021, 12, 1669. [CrossRef] [PubMed]

38. Palumbo, A.; Anderson, K. Multiple myeloma. N. Engl. J. Med. 2011, 364, 1046-1060. [CrossRef] [PubMed]

39. Harbeck, N.; Penault-Llorca, F.; Cortes, J.; Gnant, M.; Houssami, N.; Poortmans, P.; Ruddy, K.; Tsang, J.; Cardoso, F. Breast cancer. Nat. Rev. Dis. Prim. 2019, 5, 66. [CrossRef] [PubMed]

40. Vitiello, G.A.; Miller, G. Targeting the interleukin-17 immune axis for cancer immunotherapy. J. Exp. Med. 2020, $217,217$. [CrossRef] [PubMed]

41. Llovet, J.M.; Zucman-Rossi, J.; Pikarsky, E.; Sangro, B.; Schwartz, M.; Sherman, M.; Gores, G. Hepatocellular carcinoma. Nat. Rev. Dis. Prim. 2016, 2, 16018. [CrossRef]

42. Tang, X.Z.; Jo, J.; Tan, A.T.; Sandalova, E.; Chia, A.; Tan, K.C.; Lee, K.H.; Gehring, A.J.; De Libero, G.; Bertoletti, A. IL-7 licenses activation of human liver intrasinusoidal mucosal-associated invariant T cells. J. Immunol. 2013, 190, 3142-3152. [CrossRef] [PubMed]

43. Hegde, P.; Weiss, E.; Paradis, V.; Wan, J.; Mabire, M.; Sukriti, S.; Rautou, P.E.; Albuquerque, M.; Picq, O.; Gupta, A.C.; et al. Mucosal-associated invariant $\mathrm{T}$ cells are a profibrogenic immune cell population in the liver. Nat. Commun. 2018, 9, 2146. [CrossRef] [PubMed]

44. Smyth, E.C.; Lagergren, J.; Fitzgerald, R.C.; Lordick, F.; Shah, M.A.; Lagergren, P.; Cunningham, D. Oesophageal cancer. Nat. Rev. Dis. Prim. 2017, 3, 17048. [CrossRef]

45. Ajani, J.A.; Lee, J.; Sano, T.; Janjigian, Y.Y.; Fan, D.; Song, S. Gastric adenocarcinoma. Nat. Rev. Dis Prim. 2017, 3, 17036. [CrossRef]

46. Gridelli, C.; Rossi, A.; Carbone, D.P.; Guarize, J.; Karachaliou, N.; Mok, T.; Petrella, F.; Spaggiari, L.; Rosell, R. Non-small-cell lung cancer. Nat. Rev. Dis. Prim. 2015, 1, 15009. [CrossRef] [PubMed]

47. Rudin, C.M.; Brambilla, E.; Faivre-Finn, C.; Sage, J. Small-cell lung cancer. Nat. Rev. Dis Prim. 2021, 7, 3. [CrossRef]

48. Hsieh, J.J.; Purdue, M.P.; Signoretti, S.; Swanton, C.; Albiges, L.; Schmidinger, M.; Heng, D.Y.; Larkin, J.; Ficarra, V. Renal cell carcinoma. Nat. Rev. Dis. Prim. 2017, 3, 17009. [CrossRef]

49. Burd, E.M. Human papillomavirus and cervical cancer. Clin. Microbiol. Rev. 2003, 16, 1-17. [CrossRef]

50. Schadendorf, D.; Fisher, D.E.; Garbe, C.; Gershenwald, J.E.; Grob, J.J.; Halpern, A.; Herlyn, M.; Marchetti, M.A.; McArthur, G.; Ribas, A.; et al. Melanoma. Nat. Rev. Dis Prim. 2015, 1, 15003. [CrossRef]

51. Schadendorf, D.; van Akkooi, A.C.J.; Berking, C.; Griewank, K.G.; Gutzmer, R.; Hauschild, A.; Stang, A.; Roesch, A.; Ugurel, S. Melanoma. Lancet 2018, 392, 971-984. [CrossRef]

52. Pardoll, D.M. The blockade of immune checkpoints in cancer immunotherapy. Nat. Rev. Cancer 2012, 12, 252-264. [CrossRef] [PubMed]

53. Darvin, P.; Toor, S.M.; Sasidharan Nair, V.; Elkord, E. Immune checkpoint inhibitors: Recent progress and potential biomarkers. Exp. Mol. Med. 2018, 50, 1-11. [CrossRef] [PubMed]

54. Wolf, Y.; Anderson, A.C.; Kuchroo, V.K. TIM3 comes of age as an inhibitory receptor. Nat. Rev. Immunol. 2020, 20, 173-185. [CrossRef] [PubMed]

55. Armitage, J.D.; Newnes, H.V.; McDonnell, A.; Bosco, A.; Waithman, J. Fine-Tuning the Tumour Microenvironment: Current Perspectives on the Mechanisms of Tumour Immunosuppression. Cells 2021, 10, 56. [CrossRef] [PubMed]

56. Smyth, M.J.; Ngiow, S.F.; Ribas, A.; Teng, M.W. Combination cancer immunotherapies tailored to the tumour microenvironment. Nat. Rev. Clin. Oncol. 2016, 13, 143-158. [CrossRef] [PubMed]

57. Bader, J.E.; Voss, K.; Rathmell, J.C. Targeting Metabolism to Improve the Tumor Microenvironment for Cancer Immunotherapy. Mol. Cell 2020, 78, 1019-1033. [CrossRef]

58. Chang, C.H.; Qiu, J.; O’Sullivan, D.; Buck, M.D.; Noguchi, T.; Curtis, J.D.; Chen, Q.; Gindin, M.; Gubin, M.M.; van der Windt, G.J.; et al. Metabolic Competition in the Tumor Microenvironment Is a Driver of Cancer Progression. Cell 2015, 162, 1229-1241. [CrossRef]

59. Brien, A.O.; Kedia-Mehta, N.; Tobin, L.; Veerapen, N.; Besra, G.S.; Shea, D.O.; Hogan, A.E. Targeting mitochondrial dysfunction in MAIT cells limits IL-17 production in obesity. Cell Mol. Immunol. 2020, 17, 1193-1195. [CrossRef] [PubMed]

60. O’Brien, A.; Loftus, R.M.; Pisarska, M.M.; Tobin, L.M.; Bergin, R.; Wood, N.A.W.; Foley, C.; Mat, A.; Tinley, F.C.; Bannan, C.; et al. Obesity Reduces mTORC1 Activity in Mucosal-Associated Invariant T Cells, Driving Defective Metabolic and Functional Responses. J. Immunol. 2019, 202, 3404-3411. [CrossRef]

61. Zinser, M.E.; Highton, A.J.; Kurioka, A.; Kronsteiner, B.; Hagel, J.; Leng, T.; Marchi, E.; Phetsouphanh, C.; Willberg, C.B.; Dunachie, S.J.; et al. Human MAIT cells show metabolic quiescence with rapid glucose-dependent upregulation of granzyme B upon stimulation. Immunol. Cell Biol. 2018, 96, 666-674. [CrossRef]

62. Vander Heiden, M.G.; Plas, D.R.; Rathmell, J.C.; Fox, C.J.; Harris, M.H.; Thompson, C.B. Growth factors can influence cell growth and survival through effects on glucose metabolism. Mol. Cell Biol. 2001, 21, 5899-5912. [CrossRef]

63. Vander Heiden, M.G.; Cantley, L.C.; Thompson, C.B. Understanding the Warburg effect: The metabolic requirements of cell proliferation. Science 2009, 324, 1029-1033. [CrossRef]

64. Brand, A.; Singer, K.; Koehl, G.E.; Kolitzus, M.; Schoenhammer, G.; Thiel, A.; Matos, C.; Bruss, C.; Klobuch, S.; Peter, K.; et al. LDHA-Associated Lactic Acid Production Blunts Tumor Immunosurveillance by T and NK Cells. Cell Metab. 2016, 24, 657-671. [CrossRef] 
65. Fischer, K.; Hoffmann, P.; Voelkl, S.; Meidenbauer, N.; Ammer, J.; Edinger, M.; Gottfried, E.; Schwarz, S.; Rothe, G.; Hoves, S.; et al. Inhibitory effect of tumor cell-derived lactic acid on human T cells. Blood 2007, 109, 3812-3819. [CrossRef] [PubMed]

66. Harmon, C.; Robinson, M.W.; Hand, F.; Almuaili, D.; Mentor, K.; Houlihan, D.D.; Hoti, E.; Lynch, L.; Geoghegan, J.; O’Farrelly, C. Lactate-Mediated Acidification of Tumor Microenvironment Induces Apoptosis of Liver-Resident NK Cells in Colorectal Liver Metastasis. Cancer Immunol. Res. 2019, 7, 335-346. [CrossRef]

67. Westendorf, A.M.; Skibbe, K.; Adamczyk, A.; Buer, J.; Geffers, R.; Hansen, W.; Pastille, E.; Jendrossek, V. Hypoxia Enhances Immunosuppression by Inhibiting CD4+ Effector T Cell Function and Promoting Treg Activity. Cell Physiol. Biochem. 2017, 41, 1271-1284. [CrossRef]

68. Gaoatswe, G.; Kent, B.D.; Corrigan, M.A.; Nolan, G.; Hogan, A.E.; McNicholas, W.T.; O’Shea, D. Invariant Natural Killer T Cell Deficiency and Functional Impairment in Sleep Apnea: Links to Cancer Comorbidity. Sleep 2015, 38, 1629-1634. [CrossRef]

69. Ahmadzadeh, M.; Johnson, L.A.; Heemskerk, B.; Wunderlich, J.R.; Dudley, M.E.; White, D.E.; Rosenberg, S.A. Tumor antigenspecific CD8 T cells infiltrating the tumor express high levels of PD-1 and are functionally impaired. Blood 2009, 114, 1537-1544. [CrossRef] [PubMed]

70. Gehring, A.J.; Ho, Z.Z.; Tan, A.T.; Aung, M.O.; Lee, K.H.; Tan, K.C.; Lim, S.G.; Bertoletti, A. Profile of tumor antigen-specific CD8 T cells in patients with hepatitis B virus-related hepatocellular carcinoma. Gastroenterology 2009, 137, 682-690. [CrossRef] [PubMed]

71. Calzascia, T.; Masson, F.; Di Berardino-Besson, W.; Contassot, E.; Wilmotte, R.; Aurrand-Lions, M.; Rüegg, C.; Dietrich, P.Y.; Walker, P.R. Homing phenotypes of tumor-specific CD8 T cells are predetermined at the tumor site by crosspresenting APCs. Immunity 2005, 22, 175-184. [CrossRef] [PubMed]

72. Palma, G.; Barbieri, A.; Bimonte, S.; Palla, M.; Zappavigna, S.; Caraglia, M.; Ascierto, P.A.; Ciliberto, G.; Arra, C. Interleukin 18: Friend or foe in cancer. Biochim. Biophys. Acta 2013, 1836, 296-303. [CrossRef]

73. Terme, M.; Ullrich, E.; Aymeric, L.; Meinhardt, K.; Desbois, M.; Delahaye, N.; Viaud, S.; Ryffel, B.; Yagita, H.; Kaplanski, G.; et al. IL-18 induces PD-1-dependent immunosuppression in cancer. Cancer Res. 2011, 71, 5393-5399. [CrossRef]

74. Crowther, M.D.; Dolton, G.; Legut, M.; Caillaud, M.E.; Lloyd, A.; Attaf, M.; Galloway, S.A.E.; Rius, C.; Farrell, C.P.; Szomolay, B.; et al. Genome-wide CRISPR-Cas9 screening reveals ubiquitous T cell cancer targeting via the monomorphic MHC class I-related protein MR1. Nat. Immunol. 2020, 21, 178-185. [CrossRef] [PubMed]

75. Parrot, T.; Healy, K.; Boulouis, C.; Sobkowiak, M.J.; Leeansyah, E.; Aleman, S.; Bertoletti, A.; Sällberg Chen, M.; Sandberg, J.K. Expansion of donor-unrestricted MAIT cells with enhanced cytolytic function suitable for TCR-redirection. JCI Insight $2021,6$. [CrossRef] [PubMed] 